\title{
Antioxidant defence of L-glutamine on mitochondrial function in experimentally induced myocardial infarction in rats
}

\author{
Anandan R*, Hari Senthil Kumar S, Ganesan B, Suseela Mathew \& Lakshmanan PT \\ Biochemistry \& Nutrition Division, Central Institute of Fisheries Technology, Matsyapuri (PO),Cochin- 682029 , \\ India
}

\begin{abstract}
Myocardial infarction is a major public health concern and the leading cause of death all over the world. A better understanding of the processes involved in myocardial infarction has stimulated the search for biomolecules, which could limit the myocardial injury. We determined the protective activity of L-glutamine on mitochondrial function in isoprenalineinduced myocardial infarction in rats, an animal model of myocardial infarction in man. Oral pre-treatment with glutamine significantly inhibited the isoprenaline-induced changes in the levels of troponin $\mathrm{T}$ and homocysteine in the plasma. It conserved the activities of tricarboxylic acid cycle enzymes (isocitrate dehydrogenase, $\alpha$-ketoglutarate dehydrogenase, succinate dehydrogenase, malate dehydrogenase) and respiratory marker enzyme (NADH dehydrogenase) and the level of myocardial ATP content at levels comparable to that of normal controls. It also attenuated isoprenaline-induced oxidative stress in rat mitochondria and preserved the antioxidant defence system at near normal. The results indicate that the cardioprotective effect of glutamine can be correlated directly with its ability to activate the energy status and antioxidant defence system.
\end{abstract}

Keywords: isoprenaline

\section{Introduction}

Globally, myocardial infarction is a major public health concern and the leading cause of mortality. Despite understanding more about the aetiology and pathophysiology of cardiovascular disease, the burden of cardiovascular disease is likely to worsen rather than improve over the next 20 years. Developing countries such as India are also struggling to manage the impact of myocardial infarction along with the growing burden of obesity, Type II diabetes and hypertension. In terms of global burden of disease, in 1999 the World Health Organization placed myocardial infarction in sixth place and stroke in seventh place, but by 2020 they will have moved to first and fourth place, respectively. According to WHO estimates, cardiovascular disease killed 14.7 million individuals in 1990 and 17 million in 1999. It is often assumed that the myocardial infarction is a disease of affluent, industrialized countries. However, $80 \%$ of these deaths occur in low-to-middle income countries of varying size such as China, Russia, Poland, Mauritius, Argentina and India (Bonow et al. 2002). A better understanding of the processes involved in myocardial infarction has stimulated the search for biomolecules which could limit myocardial injury.

Glutamine is the most prevalent free proteic amino acid in many organs, including the heart. Traditionally considered a non-essentialamino acid, glutamine is now considered "conditionally essential" aftercritical illness, stress and injury. It plays an important role in inter-organ nitrogen exchange and the maintenance of $\mathrm{pH}$ homeostasis (Van de Poll et al. 2004). It is important as a constituent of proteins and as a central metabolite for amino acid transamination via $\alpha$-ketoglutarate and glutamate. It provides nitrogen for a number of biosynthetic pathways, serving as a precursor of the purine and pyrimidine rings of nucleic acids and nucleotides such as adenosine triphosphate (ATP) (Mora et al. 2002). Glutamine is also involved in various cellular and subcellular functions, which include pro-inflammatory 
cytokine expression, gut barrier function, immune function, cell membrane stabilization, antioxidation and detoxification (Wischmeyer 2003; Kumar \& Anandan 2007). Used as an energy substrate in most cells, this multifaceted amino acid is one of the principal free intracellular amino acids in mammalian heart cells (Suleiman et al. 1997). It is involved in the regulation of endothelial nitric oxide metabolism in the myocardium (Murphy \&Newsholme 1998). Glutamine plays a critical role in glutathione biosynthesis by providing glutamate to the glutathione system, one of the main sources of antioxidant defence in cardiac tissue (Hong et al. 1992).Significant reduction in the intracellular concentration of glutamine occurs in heart tissue during myocardial infarction (Suleiman et al. 1993). Although glutamine is assumed to participate in various important biological and physiological functions in the heart, the protective effect of glutamine on mitochondrial function in experimentally induced myocardial infarction has not been explored in detail.

Myocardial infarction induced by isoprenaline [isoproterenol; L- $\beta$-(3,4-dihydroxyphenyl)- $\alpha$-isopropylaminoethanol hydrochloride], a $\beta$-adrenergic agonist, shows many metabolic and morphologic aberrations in the myocardium of experimental animals similar to those observed in myocardial infarction in man (Geng et al. 2004). Intraperitoneal administration of isoprenaline produces necrotic lesions and increases lipid peroxidation in the myocardium, which plays a significant part in the pathogenesis of myocardial dysfunction (Rathore et al. 1998; Kumar et al. 2001). Alterations in the activities of antiperoxidative enzymes [superoxide dismutase (SOD) and catalase (CAT)] and glutathione-dependent antioxidant enzymes [glutathione peroxidase (GPX) and glutathione-S-transferase (GST)] have been reported in experimentally induced myocardial infarction in rats (Farvin et al. 2004; Shiny et al. 2005).

Here we investigate the cardioprotective effects of glutamine on myocardial mitochondrial function in isoprenaline-induced myocardial infarction in rats, with respect to changes in the levels of diagnostic markers of myocardial injury, lipid peroxidation, TCA cycle enzymes, respiratory marker enzymes and antioxidant defence status.

\section{Materials \& Methods}

L-Glutamine, isoprenaline, adenosine triphosphate, adrenaline (epinephrine) and tetraethoxy propane were obtained from M/s. Sigma Chemical Company, St. Louis, Missouri, USA. All the other chemicals used were of analytical grade.

Male Wistar strain albino rats, weighing 120-150g were selected for the study. The animals were housed individually in polyurethane cages under hygienic conditions and maintained at normal room temperature. The experiment was carried out according to the guidelines of the Committee for the Purpose of Control and Supervision of Experiments on Animals (CPCSEA), New Delhi, India and approved by the Institutional Animal Ethics Committee (IAEC). The animals were allowed standard diet [M/s Sai Feeds, Bangalore, India] and water ad libitum.

Myocardial infarction was induced in experimental animals by intraperitoneal injection of isoprenaline [11mg (dissolved in physiological saline)/ 100g body weight/ day], for 2 days (Anandan et al. 2003). The animals were divided into four groups, comprising six rats each. Rats in Group 1 (normal control) received standard diet and intragastrically administered with distilled water for a period of 20 days. Group 2 animals were orally administered with Lglutamine [100mg (dissolved in distilled water) per $\mathrm{kg}$ body-weight per day] by intragastric intubation for a period of 20 days. In Group 3, animals were administered with distilled water for a period of 20 days and then injected with isoprenaline [11mg (dissolved in physiological saline) per $100 \mathrm{~g}$ body-weight per day, intraperitoneallyfor two days] for the induction of myocardial infarction. In Group 4, the animals were pretreated with glutamine [100 mg per kg 
body-weight per day, orally for 20 days before the induction of myocardial infarction as described for Group 3. Control animals (Groups 1 and 2) were injected with physiological saline alone for two days.

At the end of the experimental period, i.e. $24 \mathrm{~h}$ after last injection of isoprenaline, the experimental animals were sacrificed and blood collected using heparin as anticoagulant for the separation of plasma. The troponin- $T$ content in plasma was determined by electrochemiluminescence immunoassay (ECLIA) using a Modular Analytics E170 (Elecsys module) immunoassay analyzer. The homocysteine content in plasma was estimated by using a Microtiter Plate Assay kit (Diazyme Laboratories). The heart tissue was dissected out immediately, and washed with chilled physiological saline. Mitochondria isolated from the heart tissue by the method of Johnson \& Lardy (1967) were used for the determination of isocitrate dehydrogenase (EC 1.1.1.42) (Bell \& Baron 1960), $\alpha$-ketoglutarate dehydrogenase (EC 1.2.4.2) (Reed \& Mukerjee 1969), succinate dehydrogenase (EC 1.3.99.1) (Slater \& Borner 1952), malate dehydrogenase (EC 1.1.1.37) (Mehler 1948), NADH dehydrogenase (EC 1.6.99.3) (Minakami et al. 1962), lipid peroxides (LPO) (Ohkawa et al. 1979), reduced glutathione (GSH) (Ellman 1959), glutathione peroxidase (EC 1.11.1.9) (Paglia \& Valentine 1967), glutathione-S-transferase (EC 2.5.1.18) (Habig et al. 1974), catalase (EC 1.11.1.6) (Takahara 1960) and superoxide dismutase (EC 1.15.1.1) (Misra \& Fridovich 1972). The level of ATP in the heart tissue was determined by the method of Ryder (1985) using a Shimadzu LC 10 ATvp HPLC. The protein content was estimated by the method of Lowry et al. (1951).

Results are expressed as mean \pm s.d. Multiple comparisons of the significant analysis of variance were performed by Tukey's multiple comparison test. A $P$-value $<0.05$ was considered as statistically significant. All data were analyzed using SPSS 10.0 for Windows.

\section{Results}

Levels of troponin-T (Fig. 1) and homocysteine (Fig. 2) in the plasma of showed significant increases in Group 3 isoprenaline-administered rats as compared to normal control rats. Oral administration of glutamine significantly reduced isoprenaline-induced elevations in the levels of troponin $\mathrm{T}$ and homocysteine as compared to Group 3 animals.

Table 1 shows the activities of TCA cycle enzymes and respiratory marker enzymes in heart mitochondria of normal and experimental groups of rats. There were significant reductions noticed in the Group 3 isoprenaline-administered rats. Oral treatment with glutamine resulted in the maintenance of these mitochondrial enzyme activities at nearnormallevels compared to Group 3 isoprenaline-induced myocardial infarcted rats. It also significantly reduced the isoprenaline-induced decline in ATP content (Fig.3) in the heart tissue of experimental rats.

Table 2 shows the levels of lipid peroxidation and reduced glutathione, and the activities of glutathione-dependent anti-oxidant enzymes (GPX and GST) and antiperoxidative enzymes (CAT and SOD) in heart mitochondria of normal and experimental groups of rats. Injection of isoprenaline caused significant elevation in the level of lipid peroxidation in the heart mitochondria of Group 3 rats compared to Group 1 normal rats. This was parallelled by a decline in the level of reduced glutathione and the activities of glutathione-dependent anti-oxidant enzymes and anti-peroxidative enzymes. Administration of glutamine significantly reduced isoprenaline-induced oxidative stress and maintained the mitochondrial anti-oxidant defence system in heart tissue at near-normal. The Group 2 normal rats receiving glutamine alone did not show any significant change when compared with Group 1 normal rats, indicating that it does not per se have any adverse effects. 


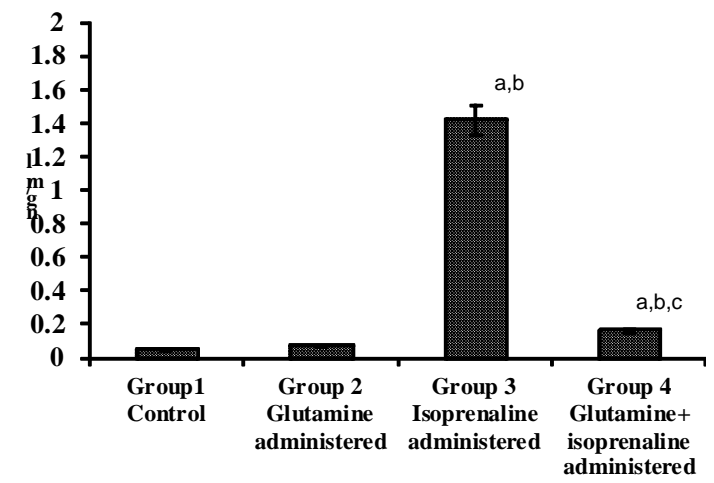

Figure 1: Levels of troponin $\mathrm{T}$ in plasma of control and experimental groups of rats. (mean \pm $\mathrm{sd}, \mathrm{n}=6) .{ }^{\mathrm{a}} \mathrm{P}<0.001$ compared with Group 1 control animals; ${ }^{\mathrm{b}} \mathrm{P}<0.001$ compared with Group 2 glutamine-administered normal rats; ${ }^{\mathrm{c}} \mathrm{P}<0.001$ compared with Group 3 isoprenaline-induced myocardial infarcted rats.

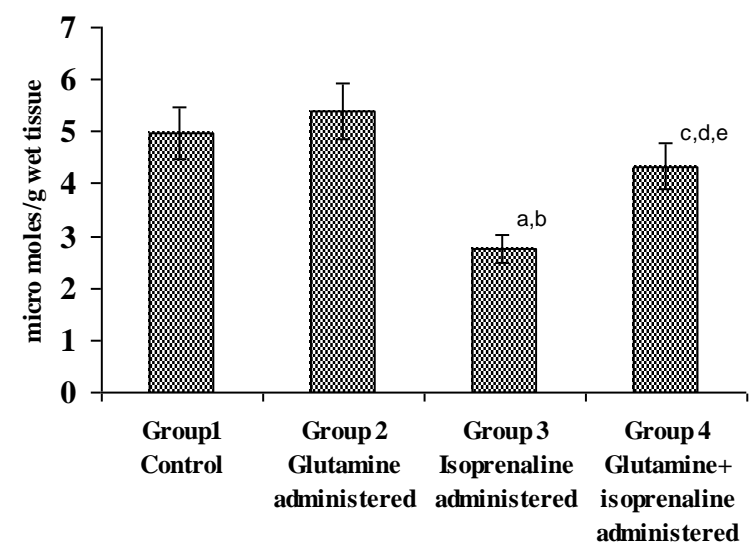

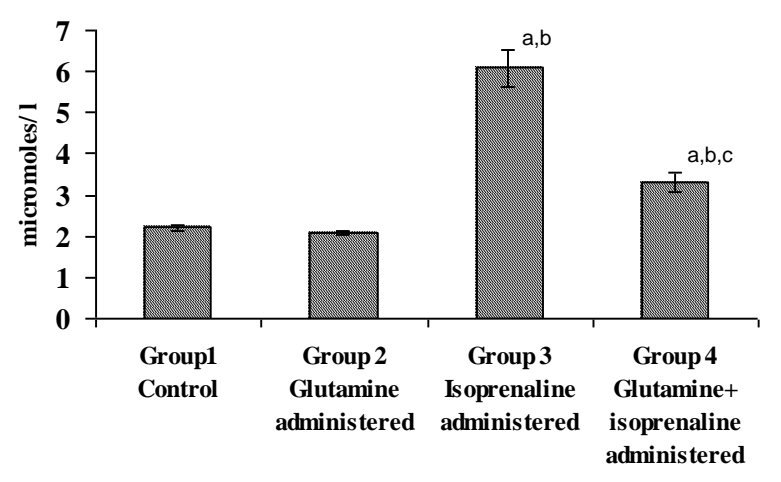

Figure 2: Levels of homocysteine in plasma of control and experimental groups of rats. (mean $\pm \mathrm{sd}, \mathrm{n}=6) .{ }^{\mathrm{a}} \mathrm{P}<0.001$ compared with Group 1 control animals; ${ }^{\mathrm{b}} \mathrm{P}<0.001$ compared with Group 2 glutamine-administered normal rats; ${ }^{\mathrm{c}} \mathrm{P}<0.001$ compared with Group 3 isoprenalineinduced myocardial infarcted rats.

Figure 3: Levels of ATP in the heart tissue of control and experimental groups of rats. (mean \pm sd, $n=6) .{ }^{a} \mathrm{P}<0.001$ compared with Group 1 control animals; ${ }^{\mathrm{b}} \mathrm{P}<0.001$ compared with Group 2 glutamine-administered normal rats; ${ }^{\mathrm{c}} \mathrm{P}<0.001$ compared with Group 3 isoprenaline-induced myocardial infarcted rats; ${ }^{\mathrm{d}} \mathrm{P}<0.01$ compared with Group 2 animals; ${ }^{\mathrm{e}} \mathrm{P}<0.05$ compared with Group 1 animals. 


\begin{tabular}{|c|c|c|c|c|}
\hline Parameters & $\begin{array}{l}\text { Group 1 } \\
\text { (control) }\end{array}$ & $\begin{array}{l}\text { Group } 2 \\
\text { (glutamine) }\end{array}$ & $\begin{array}{l}\text { Group } 3 \\
\text { (isoprenaline) }\end{array}$ & $\begin{array}{l}\text { Group } 4 \\
\text { (glutamine } \\
+ \text { isoprenaline) }\end{array}$ \\
\hline Isocitrate dehydrogenase & $698 \pm 58$ & $712 \pm 61$ & $454 \pm 39^{a, b}$ & $659 \pm 50^{c}$ \\
\hline Succinate dehydrogenase & $253 \pm 20$ & $248 \pm 22$ & $121 \pm 10^{\mathrm{a}, \mathrm{b}}$ & $218 \pm 20^{\mathrm{c}}$ \\
\hline$\alpha$-Ketoglutarate dehydrogenase & $108 \pm 9$ & $117 \pm 12$ & $47.5 \pm 3.6^{\mathrm{a}, \mathrm{b}}$ & $93.8 \pm 10.5^{b, c}$ \\
\hline Malate dehydrogenase & $368 \pm 41$ & $384 \pm 38$ & $184 \pm 13^{a, b}$ & $341 \pm 29^{c}$ \\
\hline NADH-dehydrogenase & $33.4 \pm 5.9$ & $38.7 \pm 4.5^{\mathrm{d}}$ & $18.6 \pm 1.0^{\mathrm{a}, \mathrm{b}}$ & $27.6 \pm 1.2^{\mathrm{b}, \mathrm{c}, \mathrm{d}}$ \\
\hline
\end{tabular}

Table 1: Activities of isocitrate dehydrogenase, succinate dehydrogenase, $\alpha$-ketoglutarate dehydrogenase, malate dehydrogenase and NADH-dehydrogenase in the heart mitochondria of normal and experimental groups of rats.

Means $\pm \mathrm{sd}, \mathrm{n}=6$. Values expressed: Isocitrate dehydrogenase, $\mathrm{nmol}$ of $\alpha$-ketoglutarate formed $\min ^{-1}(\mathrm{mg} \text { protein })^{-1} ; \alpha$ Ketoglutarate dehydrogenase, nmol of ferrocyanide formed $\min ^{-1}(\mathrm{mg} \text { protein })^{-1}$; Succinate dehydrogenase, $\mu$ mol of succinate oxidized $\min ^{-1}$ (mg protein $)^{-1}$; Malate dehydrogenase, $\mu$ mol of NADH oxidized $\min ^{-1}$ (mg protein $)^{-1}$; NADHdehydrogenase, $\mu$ mol of NADH oxidized $\min ^{-1}$ (mg protein $)^{-1} .{ }^{a} \mathrm{P}<0.001$ compared with Group 1 control animals; ${ }^{b} \mathrm{P}<0.001$ compared with Group 2 glutamine-administered normal rats; ${ }^{\mathrm{C}} \mathrm{P}<0.001$ compared with Group 3 isoprenaline-induced myocardial infarcted rats; ${ }^{\mathrm{d}} \mathrm{P}<0.05$ compared with Group 1 control animals.

\begin{tabular}{lllll}
\hline Parameters & $\begin{array}{l}\text { Group 1 } \\
\text { (control) }\end{array}$ & $\begin{array}{l}\text { Group 2 } \\
\text { (glutamine) }\end{array}$ & Group 3 (isoprenaline) & $\begin{array}{l}\text { Group 4 } \\
\text { (glutamine } \\
\text { isoprenaline) }^{\text {isom }}\end{array}$ \\
\hline LPO & $0.158 \pm 0.042$ & $0.129 \pm 0.036$ & $0.475 \pm 0.074^{\mathrm{a}, \mathrm{b}}$ & $0.196 \pm 0.038^{\mathrm{c}, \mathrm{f}}$ \\
GSH & $3.78 \pm 0.21$ & $4.18 \pm 0.32^{\mathrm{d}}$ & $2.41 \pm 0.15^{\mathrm{a}, \mathrm{b}}$ & $3.54 \pm 0.18^{\mathrm{b}, \mathrm{c}}$ \\
CAT & $6.45 \pm 0.41$ & $6.78 \pm 0.37$ & $3.15 \pm 0.18^{\mathrm{a}, \mathrm{b}}$ & $5.91 \pm 0.34^{\mathrm{b}, \mathrm{c}}$ \\
SOD & $3.16 \pm 0.14$ & $3.35 \pm 0.18^{\mathrm{e}}$ & $1.43 \pm 0.05^{\mathrm{a}, \mathrm{b}}$ & $3.05 \pm 0.11^{\mathrm{b}, \mathrm{c}}$ \\
GPx & $2.79 \pm 0.24$ & $3.12 \pm 0.29$ & $2.22 \pm 0.18^{\mathrm{a}, \mathrm{b}}$ & $2.82 \pm 0.26^{\mathrm{c}}$ \\
GST & $1175 \pm 98$ & $1201 \pm 84$ & $491 \pm 36^{\mathrm{a}, \mathrm{b}}$ & $820 \pm 73^{\mathrm{a}, \mathrm{b}, \mathrm{c}}$ \\
\hline
\end{tabular}

Table 2: Levels of lipid peroxides (LPO) and reduced glutathione (GSH) and the activities of glutathione peroxidase (GPx), glutathione-S-transferase (GST), catalase (CAT) and superoxide dismutase (SOD) in the heart mitochondria of normal and experimental groups of rats.

Means $\pm \mathrm{sd}, \mathrm{n}=6$. Values expressed: LPO, $\mathrm{nmol}$ malondialdehyde released (mg protein) ${ }^{-1}$; GSH, $\mu$ mol g $^{-1}$ wet tissue; GPx, nmol GSH oxidized $\min ^{-1}\left(\mathrm{mg}\right.$ protein) ${ }^{-1}$; GST, $\mu$ mol 1-chloro-2,4-dinitrobenzene conjugate formed $\mathrm{min}^{-1}$ (mg protein) ${ }^{-1}$; CAT, nmol $\mathrm{H}_{2} \mathrm{O}_{2}$ decomposed $\min ^{-1}$ (mg protein) ${ }^{-1}$; SOD, one unit of the SOD activity is the amount of protein required to give $50 \%$ inhibition of epinephrine autoxidation. ${ }^{\mathrm{a}} \mathrm{P}<0.001$ compared with Group 1 control animals; ${ }^{\mathrm{b}} \mathrm{P}<0.001$ compared with Group 2 glutamine-administered normal rats; ${ }^{c} \mathrm{P}<0.001$ compared with Group 3 isoprenaline-induced myocardial infarcted rats; ${ }^{\mathrm{d}} \mathrm{P}<0.01$ compared with Group 1 control animals; ${ }^{\circ} \mathrm{P}<0.05$ compared with Group 2 glutamine-administered normal rats; ${ }_{\mathrm{P}}^{\mathrm{P}}<0.05$ compared with Group 1 control rats.

\section{Discussion}

The significant elevations noticed in the levels of troponin $\mathrm{T}$ and homocysteine in Group 3 isoprenaline-treated rats indicated the severity of isoprenaline-induced infarction in the rat myocardium. Recentlymyocardial troponin $\mathrm{T}$ has increasingly been used as a well-established indicator for diagnosing myocardial infarction (Roppolo et al. 1999). Investigations by Senaratne et al. (2000) revealed that hyperhomocysteinemia is associated with an increased risk of cardiovascular diseases independently of classical risk factors. In the present study, oral pretreatment with glutamine maintained the levels of troponin $\mathrm{T}$ and homocysteine in the blood stream at near normal. It probably did so by maintaining the delicate balance of tonicity in cells in the myocardium. Glutamine concentration is a major factor involved in the processes of cell 
volume regulation ( $\mathrm{Wu}$ 1995). Cell volume affects the most basic processes of cell function, and hence exerts an important role in the onset, severity, and outcome of myocardial infarction. Earlier studies (Parolari et al. 1997) indicated that glutamine administration can avert the severe osmolar changes associated with possible cell death.

Reduction in mitochondrial energy-yielding enzymes coupled with a concomitant decline in the level of myocardial ATP content in Group 3 rats indicated that the mitochondrial oxidative phosphorylation was operating at very much lower rate despite the higher energy demand in the ischemic myocardium. In the present study, oral glutamine intake maintained the level of ATP and the activities of mitochondrial enzymes at near-normal in Group 4relative to Group 3 rats. Increased ATP production may reduce myocardial oxygen demand, which could result in preservation of high-energy phosphate stores under ischemic conditions. Glutamine is utilized as a major energy source and drives mitochondrial ATP formation. The first step for glutamine catabolism in the mitochondria is its transport through the inner mitochondrial membrane. Glutamine is transported in the mitochondria by a protein-catalyzed process. Glutamine participates in energy production as well as in the synthesis of nucleic acid components and proteins in mitochondria (Kvamme et al. 2000). Ischemic cells utilize glutamine for energy production, and a fall in tissue glutamine does occur in the hearts of patients undergoing coronary artery bypass surgery (Suleiman et al. 1997).

Oxidative stress is the result of excessive production of oxidant species and/or depletion of intracellular anti-oxidant defences, leading to an imbalance in the redox status of myocardial cells. Mitochondria are a potential target of injury by oxygen radicals, and an alteration in mitochondrial membrane function is an important component of oxidative stress in cells. In the present study, the level of lipid peroxidation was significantly higher in the heart mitochondria of Group 3 isoprenaline-administrated rats relative to Group 1 controls. This was parallelled by reduction in the level of reduced glutathione and the activities of glutathionedependent anti-oxidant enzymes and anti-peroxidative enzymes in the heart mitochondria of infarction-induced Group 3 rats. The reduction noticed in the level of GSH was probably due to decreased synthesis of glutathione, and the decreased availability of GSH might have resulted in the lowered activities of GPx and GST. Reduction in the activities of SOD and catalase may lead to the generation of $\mathrm{O}^{2-}$ and $\mathrm{H}_{2} \mathrm{O}_{2}$, which in turn can form hydroxyl radicals $\left(\mathrm{OH}^{\circ}\right)$ and bring about a number of reactions harmful to the cellular and subcellular membranes.

The administration of glutamine significantly prevented the isoprenaline-induced lipid peroxidation and also maintained the level of reduced glutathione and the activities of antioxidant enzymes in the heart mitochondria of Group 4 rats at near-normal levels. It probably did so by its anti-oxidant property. Mates et al. (2002) demonstrated that glutamine is used to supply glutamate and cysteine, perhaps for glutathione biosynthesis. Glutamine has been shown to preserve total glutathione levels after injury/ischemia (Prem et al. 1999). The quenching of reactions mediated by reactive oxygen species decreases oxidized protein levels and normalizes enzyme activities. Glutamine via glutamate and glutathione biosynthesis can prevent oxidation of highly sensitive enzymes and thus protect the functions of the myocardium. Matillaet al. (2000) indicated that glutathione concentration was normalized in animals supplemented with glutamine or alanyl glutamine. It has been shown previously (Hong et al. 1992) that theadministration of glutamine-supplemented nutrition protects the liver and improves survival during acetaminophen-induced hepatic injury in rats, an effect probably due to the maintenance of liver glutathione. Hence the administration of glutamine that protects the rat myocardium from oxidative stress during isoprenaline-induced myocardial infarction is an effect probably related to the normal maintenance of heart glutathione, which protects myocardial cellular and subcellular membranes from oxidative damage by attenuating lipid peroxidation. 
In the present study, oral glutamine intake was observed to exhibit cardioprotective effects as demonstrated by a significant decrease in troponin $\mathrm{T}$ and homocysteiene in the blood plasma of rats induced with myocardial infarction. Moreover, glutamine enhanced the mitochondrial energy status and anti-oxidant defence of the myocardium, suggesting that the activation of ATP production and reduction of oxidative stress is likely to play a role in the mechanism of its cardioprotective effects. The cardioprotective effect of glutamine can be correlated directly with its ability to activate the energy status of the anti-oxidant defence system. Thus glutamine may be useful as a safe and effective chemopreventive agent in the management of cardiovascular diseases.

\section{Acknowledgements}

Financial aid from the Indian Council of Agricultural Research for S. Hari Senthil Kumar is gratefully acknowledged. The authors thank the Director, Central Institute of Fisheries Technology, Cochin, for granting permission to publish this paper. We appreciate the technical assistance provided by P.A. Jaya \& Dr.G. Usha Rani.

\section{References}

Anandan R, Asha KK, Ammu K, Suseela M \& Nair PGV (2003) Effects of peroxidised PUFA on tissue defense system in experimentally induced myocardial infarction in rats. In: Seafood safety. Society of Fisheries Technologists (India), Cochin, India. pp. 330-335

Bell JL \&Baron DN (1960) A colorimetric method for determination of isocitric dehydrogenase.Clinica Chimica Acta 5: 740-747

Bonow RO, Smaha LA, Smith SC, Mensah GA \& Lenfant G (2002) The international burden of cardiovascular disease: responding to the emerging global epidemic. Circulation 106: 1602-1605

Dennis T, Mangano Miao Y, Iulia C \& Dietzel C (2006)Post-reperfusion myocardial infarction: long-term survival improvement using adenosine regulation with acadesine. Journal of the American College of Cardiology48: 206-214

Ellman GL (1959) Tissue sulfhydril groups. Archives of Biochemistry \& Biophysics 82: 70-77

Farvin KHS, Anandan R, Kumar SHS, Shiny KS, Sankar TV \& Thankappan TK (2004) Effect of squalene on tissue defense system in isoproterenol-induced myocardial infarction in rats. Pharmacology Research 50: 231-236

Geng B, Chang L, Pan C, Qi Y, Zhao J, Pang Y, Du J \& Tang C (2004) Endogenous hydrogen sulfide regulation of myocardial injury induced by isoproterenol. Biochemistry \& Biophysics Research Communications 318: 756-763

Habig WH, Pabst MJ \& Jakoby WB (1974) Glutathione-S-transferases: the first enzymatic step in mercapturic acid formation. Journal of Biological Chemistry 249: 7130-7139

Hong RW, Rounds JD, Helton WS, Robinson MK \&Wilmore DW (1992) Glutamine preserves liver glutathione after lethal hepatic injury.Annals of Surgery 215:114-119

Johnson D \& Lardy H (1967) Isolation of liver or kidney mitochondria. In: Methods in Enzymology. Vol. 10. London; Academic Press; pp 94-96

Kumar SHS \& Anandan R (2007) Biochemical studies on the cardioprotective effect of glutamine on tissue antioxidant defense system in isoprenaline-induced myocardial infarction in rats. Journal of Clinical Biochemistry \& Nutrition40: 49-55

Kumar SHS, Anandan R, Devaki T \& Kumar MS (2001) Cardioprotective effects of Picrorhiza kurroa against isoproterenol-induced myocardial stress in rats. Fitoterapia 72: 402-405.

Kvamme E, Roberg B \& Torgner IA (2000) Glutamine transport in brain mitochondria. Neurochemistry International 37: 131-138

Lowry OH, Rosebrough NJ, Farr AL \& Randall, RJ (1951) Protein measurement with Folin phenol reagent. Journal of Biological Chemistry 193: 265-275

Mates JM, Gomez CP, Castro IN, Asenjo M \& Marquez J (2002)Glutamine and its relationship with intracellular redox status, oxidative stress and cell proliferation/death. International Journal of Biochemistry \&Cell Biology34: 439-458

Matilla B, Ortiz J, Gonzalez P, Garcia-Diez F, Jorquera F, Culebras JM, Gonzalez-Gallego J \& Tunon M.J (2000) Effects of parenteral nutrition supplemented with glutamine or glutamine dipeptides on liver antioxidant and detoxication systems in rats. Nutrition 16: 125-128

Mehler AH, Kornberg A, Grisolia S \& Ochoa S (1948) The enzymatic mechanism of oxidation-reductions between malate or isocitrate and pyruvate. Journal of Biological Chemistry174: 961 - 977 
Mullane K \&Bullough D (1995) Harnessing an endogenous cardioprotective mechanism: cellular sources and sites of action of adenosine. Journal of Molecular \& Cellular Cardiology 27:1041-1054

Minakami S, Ringler RL \& Singer TP (1962) Studies on the Respiratory Chain-linked Dihydrodiphosphopyridine Nucleotide Dehydrogenase. I. Assay of the enzyme in particulate and in soluble preparations. Journal of Biological Chemistry237: $569-576$

Misra HP \& Fridovich I (1972) The role of superoxide anion in the auto-oxidation of epinephrine and simple assay for superoxide dismutase. Journal of Biological Chemistry 247: 3170-3175

Mora LO, Antunes LMG, Francescato HDC \& Bianchi MLP (2002) The effects of oral glutamine on cisplatininduced genotoxicity in Wistar rat bone marrow cells. Mutation Research. 518: 65-70

Murphy C \& Newsholme P (1998) Importance of glutamine metabolism in murine macrophages and human monocytes to L-arginine biosynthesis and rates of nitrite or urea production. Clinical Science (London) 95 : 397-407

Ohkawa H, Ohishi N \& Yagi K (1979) Assay for lipid peroxides in animal tissue by thiobarbituric acid reaction. Analytical Biochemistry 95: 351-358

Padma VV \&Devi CS (2002) Effect of fish oil on mitochondrial respiration in isoproterenol induced myocardial infarction in rats. Indian Journal of Experimental Biology 40: 268-272

Paglia DE \& Valentine WN (1967) Studies on the quantitative and qualitative characterization of erythrocyte glutathione peroxidase. Journal of Laboratory \& Clinical Medicine 70: 158-169

Parolari A, Sala R, Antona C, Bussolati O, Alamanni F, Mezzadri P,Dall'Asta V, Gazzola GC\&Biglioli P (1997) Hypertonicity induces injury to cultured human endothelium: attenuation by glutamine.Annals of Thoracic Surgery 64: 1770-1775

Prem JT, Eppinger M, Lemmon G, Miller S, Nolan D \& Peoples J (1999) The role of glutamine in skeletal muscle ischemia/reperfusion injury in the rat hind limb model. American Journal of Surgery 178: 147-150

Rathore N, John S, Kale M \& Bhatnagar D (1998) Lipid peroxidation and antioxidant enzymes in isoproterenol induced oxidative stress in rat tissues. Pharmacological Research 38: 297-303

Reed LJ \& Mukerjee RB (1969) a-ketoglutarate dehydrogenase complex from Eschericia coli. In: Methods in Enzymology. Vol. 13. London; Academic Press: pp 53-61

Roppolo LP, Fitzgerald R, Dillow J, Ziegler T, Rice M \& Maisel A (1999) A comparison of troponin T and troponin I as predictors of cardiac events in patients undergoing chronic dialysis at a Veteran's Hospital: a pilot study. Journal ofthe American College of Cardiology 34: 448-454

Ryder JM (1985) Determination of adenosine triphosphate and its breakdown products in fish muscle by high performance liquid chromatography. Journal of Agricultural \& Food Chemistry 33: 678-680

Senaratne MP, Griffiths J \& Nagendran J (2000) Elevation of plasma homocysteine levels associated with acute myocardial infarction. Clinical \& Investigative Medicine 23: 220-226

Shiny KS, Kumar SHS, Farvin KHS, Anandan R \& Devadasan K (2005) Protective effect of taurine on myocardial antioxidant status in isoprenaline-induced myocardial infarction in rats. Journal of Pharmacy \& Pharmacology57: 1313-1317

Slater EC \& Borner WD (1952) The effect of fluoride on the succinic oxidase system. Biochemical Journal 52: 185-196

Suleiman MS, Dihmis WC, Caputo M, Angelini GD \&Bryan AJ (1997) Changes in myocardial concentration of glutamate and aspartate during coronary artery surgery.American Journal of Physiology 272: 1063-1069

Suleiman MS, Fernando HC, Dihmis WC, Hutter JA \& Chapman RA (1993) A loss of taurine and other amino acids from ventricles of patients undergoing bypass surgery. British Heart Journal 69: 241-245

Suleiman MS, Moffatt AC, Dihmis WC, Caputo M, Hutter JA, Angelini GD \& Bryan A.J (1997) Effect of ischaemia and reperfusion on the intracellular concentration of taurine and glutamine in the hearts of patients undergoing coronary artery surgery. Biochimica \& Biophysica Acta 1324: 223-31

Takahara S, Hamilton BH, Nell JV, Ogubra TY \& Nishimura ET (1960) Hypocatalasemia: a new genetic carrier state. Journal of Clinical Investigation 39: 610-619

Van de Pol MC, Soeters PB, Deutz NE, Fearon KC \&Dejong CH (2004) Renal metabolism of amino acids: its role in interorgan amino acid exchange.American Journal of Clinical Nutrition 79: 185-197

Wischmeyer PE (2003) Clinical applications of L-glutamine: past, present, and future. Nutrition \& Clinical Practice 18: 377-385

Wu G \& Flynn NE (1995) Regulation of glutamine and glucose metabolism by cell volume in lymphocytes and macrophages. Biochimica \& Biophysica Acta1243: 343-350 


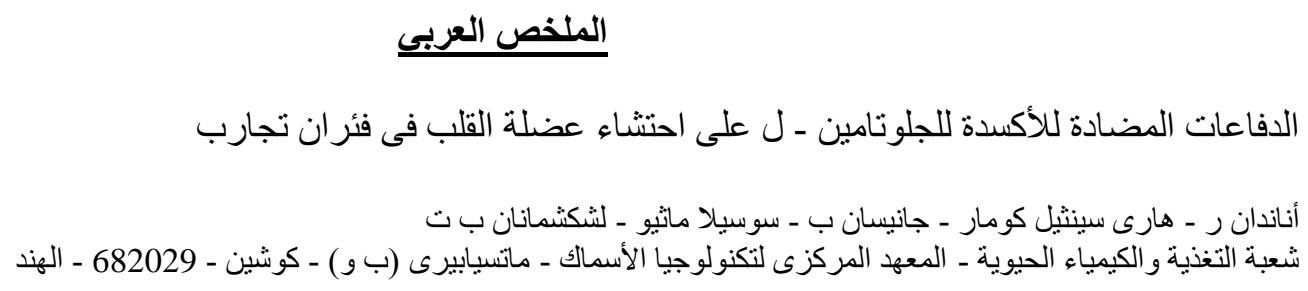

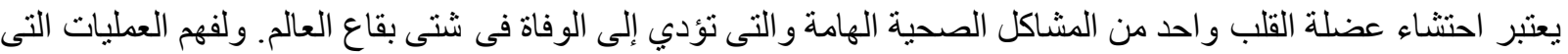

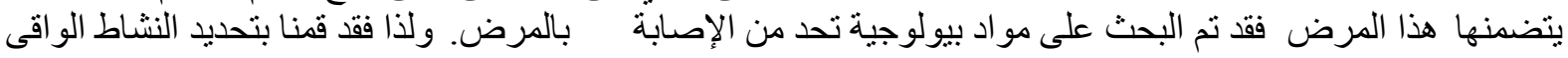

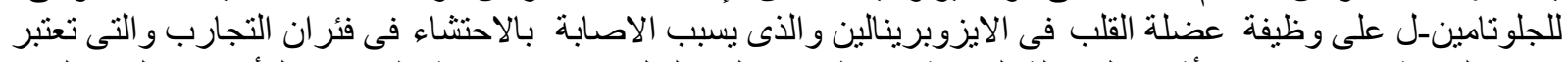

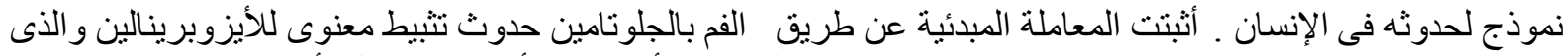

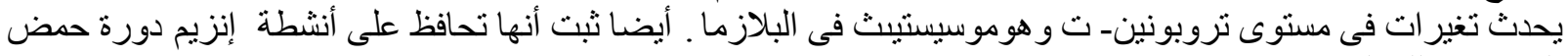
الكاربو كسيلك الثلاثى (isocitrate dehydrogenase, $\alpha$-ketoglutarate dehydrogenase, succinate dehydrogenase, malate dehydrogenase)، و الإنزيم

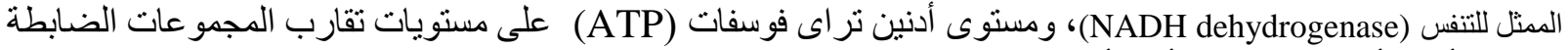

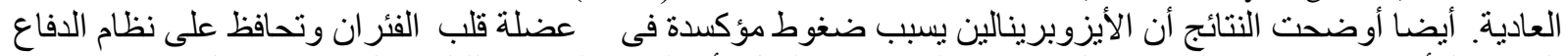

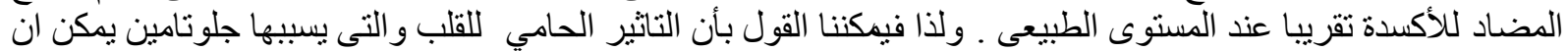
ترتبط مباشرة مع قدرته على تنشيط حالة الطاقة وكنللك تتشيط نظام الدفاع ضد الند المو أد المؤكسدة. 